CRYSTALLOGRAPHIC COMMUNICATIONS

ISSN 2056-9890

Received 18 May 2020

Accepted 24 May 2020

Edited by W. T. A. Harrison, University of Aberdeen, Scotland

₹ Additional correspondence author, e-mail: edwardt@sunway.edu.my.

Keywords: crystal structure; pyrrolidine; Hirshfeld surface analysis; $\mathrm{NCl}$ plots; computational chemistry.

CCDC reference: 2005478

Supporting information: this article has supporting information at journals.iucr.org/e

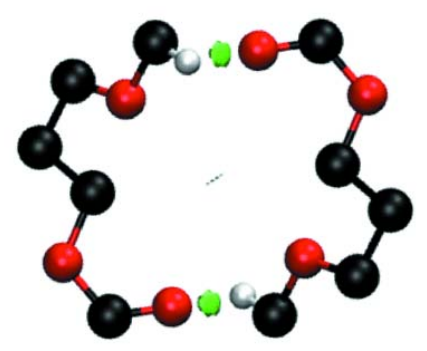

OPEN $\partial$ ACCESS

\section{1-Ethyl 2-methyl 3,4-bis(acetyloxy)pyrrolidine-1,2- dicarboxylate: crystal structure, Hirshfeld surface analysis and computational chemistry}

\author{
Sofia Dallasta Pedroso, ${ }^{a}$ Ignez Caracelli, ${ }^{\mathrm{b} *}$ Julio Zukerman-Schpector, ${ }^{\mathrm{a}}$ Monica \\ Soto-Monsalve, ${ }^{\mathrm{c}}$ Regina H. De Almeida Santos, ${ }^{\mathrm{C}}$ Carlos Roque D. Correia, ${ }^{\mathrm{d}}$ Ariel L. \\ Llanes Garcia, ${ }^{\mathrm{d}}$ Huey Chong Kwong ${ }^{\mathrm{e}}$ and Edward R. T. Tiekink ${ }^{\mathrm{e}} \neq$
}

\begin{abstract}
aLaboratório de Cristalografia, Esterodinâmica e Modelagem Molecular, Departamento de Química, Universidade Federal de São Carlos, 13565-905 São Carlos, SP, Brazil, 'b Departmento de Física, Universidade Federal de São Carlos, $13565-$ 905 São Carlos, SP, Brazil, 'Instituto de Química de São Carlos, Universidade de São Paulo, São Carlos, SP, Brazil, dInstituto de Química, Universidade Estadual de Campinas, UNICAMP, CP 6154, CEP 13084-917 Campinas, Brazil, and

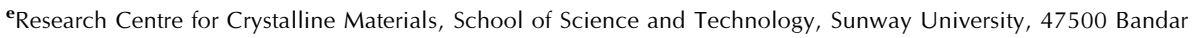
Sunway, Selangor Darul Ehsan, Malaysia. *Correspondence e-mail: ignez@df.ufscar.br
\end{abstract}

The title compound, $\mathrm{C}_{13} \mathrm{H}_{19} \mathrm{NO}_{8}$, is based on a tetra-substituted pyrrolidine ring, which has a twisted conformation about the central $\mathrm{C}-\mathrm{C}$ bond; the $\mathrm{C}_{\mathrm{m}}-\mathrm{C}_{\mathrm{a}}-$ $\mathrm{C}_{\mathrm{a}}-\mathrm{C}_{\mathrm{me}}$ torsion angle is $38.26(15)^{\circ}[\mathrm{m}=$ methylcarboxylate, $\mathrm{a}=$ acetyloxy and me $=$ methylene]. While the $\mathrm{N}$-bound ethylcarboxylate group occupies an equatorial position, the remaining substituents occupy axial positions. In the crystal, supramolecular double-layers are formed by weak methyl- and methylene-C $-\mathrm{H} \cdots \mathrm{O}$ (carbonyl) interactions involving all four carbonyl-O atoms. The two-dimensional arrays stack along the $c$ axis without directional interactions between them. The Hirshfeld surface is dominated by $\mathrm{H} \cdots \mathrm{H}$ $(55.7 \%)$ and $\mathrm{H} \cdots \mathrm{C} / \mathrm{C} \cdot \mathrm{H}(37.0 \%)$ contacts; $\mathrm{H} \cdots \mathrm{H}$ contacts are noted in the inter-double-layer region. The interaction energy calculations point to the importance of the dispersion energy term in the stabilization of the crystal.

\section{Chemical context}

A number of diseases, especially diabetes but also including viral diseases, cystic fibrosis and cancer, can be treated with $\alpha$ glucosidase inhibitors (Dhameja \& Gupta, 2019; Kiappes et al., 2018); for a review of the relevant patent literature, see Brás et al. (2014). Imino- and aza-sugars are strong inhibitors of the enzyme and are attracting current interest for chaperone therapy of Gaucher disease (Matassini et al., 2020). The trihydroxyl-substituted compound, aminociclitol, (I), is a known $\alpha$-glucosidase inhibitor and is a natural product, being found in several plants (Assefa et al., 2020). The synthesis of (I) can proceed from several key intermediates (Garcia, 2008; Liu \& $\mathrm{Ma}, 2017)$ and it is this consideration that prompted the structural investigation of the title compound, $\mathrm{C}_{13} \mathrm{H}_{19} \mathrm{NO}_{8}$, (II). Specifically, the $\mathrm{HCl}$ salt of (I) can be prepared from (II) after being subjected to a sequence of reactions comprising a reduction step, reflux acid hydrolysis, chromatographic purification on ion-exchange resin Dowex- $\mathrm{H}^{+}$and, finally, hydrochloride formation. In this way, (I) $\cdot \mathrm{HCl}$ was obtained in $67 \%$ yield (Garcia, 2008). In connection with supporting structural studies (Zukerman-Schpector et al., 2017) of crucial intermediates related to the synthesis of pharmacologically active (I), herein, the crystal and molecular structures of (II) are described. This is complemented by a detailed analysis of the 
supramolecular architecture by Hirshfeld surface analysis, non-covalent interactions plots and computational chemistry.

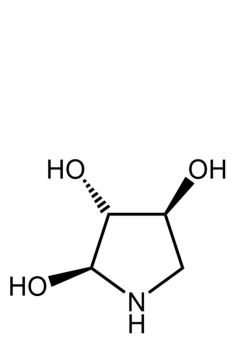

(I)

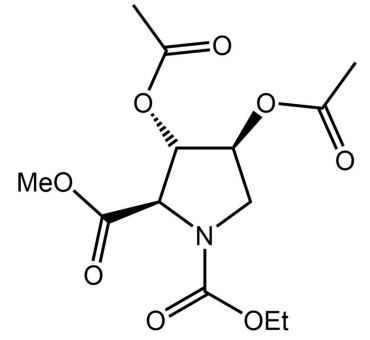

(II)

\section{Structural commentary}

The molecular structure of (II), Fig. 1, features a tetrasubstituted pyrrolidine ring. The conformation of the fivemembered ring is best described as being twisted about the $\mathrm{C} 2-\mathrm{C} 3$ bond; the $\mathrm{C} 1-\mathrm{C} 2-\mathrm{C} 3-\mathrm{C} 4$ torsion angle is $38.26(15)^{\circ}$ indicating a $(+) s y n$-clinal configuration. With respect to the five-membered ring, the $N$-bound methylcarboxylate substituent occupies an equatorial position; the sum of angles about the $\mathrm{N} 1$ atom amounts to $360^{\circ}$, indicating this is an $s p^{2}$ centre. At the $\mathrm{C} 1-\mathrm{C} 3$ centres, the methylcarboxylate and $2 \times$ acetyloxy substituents, respectively, occupy axial positions. For the molecule illustrated in Fig. 1, the chirality of each of the C1-C3 atoms is $R, S$ and $S$, respectively; the centrosymmetric unit cell contains equal numbers of each enantiomer. When viewed towards the approximate plane through the pyrrolidine ring, the $\mathrm{N}$-bound substituent is approximately co-planar, the C2-acetyloxy lies to one side of the plane, and the C1- and C3-substituents lie to the other side.

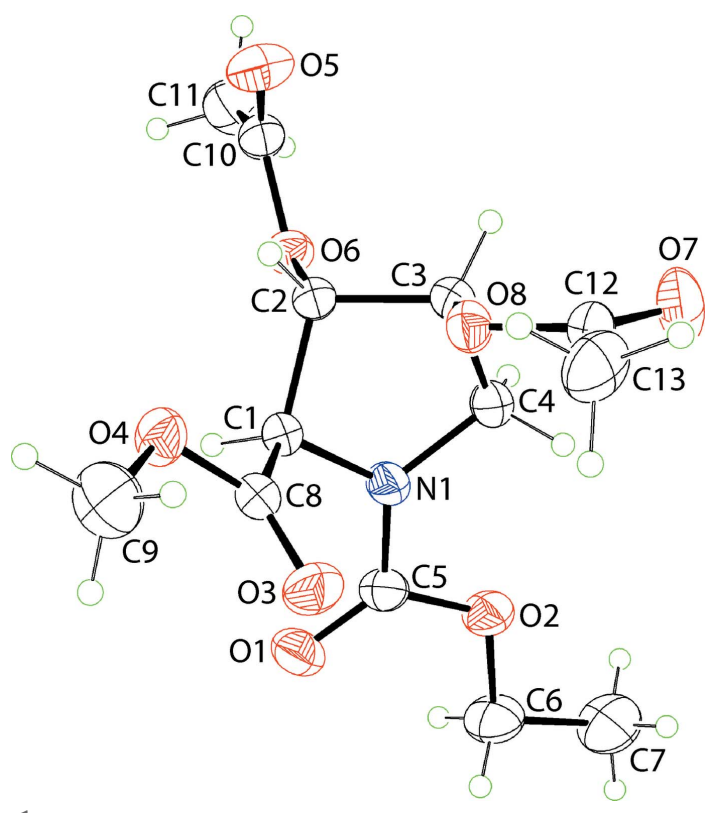

Figure 1

The molecular structure of (II), showing the atom-labelling scheme and displacement ellipsoids at the $35 \%$ probability level.
Table 1

Hydrogen-bond geometry $\left(\AA,^{\circ}\right)$.

\begin{tabular}{lllll}
\hline$D-\mathrm{H} \cdots A$ & $D-\mathrm{H}$ & $\mathrm{H} \cdots A$ & $D \cdots A$ & $D-\mathrm{H} \cdots A$ \\
\hline $\mathrm{C} 9-\mathrm{H} 9 B \cdots \mathrm{O} 5^{\mathrm{i}}$ & 0.96 & 2.53 & $3.403(3)$ & 151 \\
$\mathrm{C} 3-\mathrm{H} 3 \cdots \mathrm{O} 1^{\mathrm{ii}}$ & 0.98 & 2.62 & $3.419(2)$ & 139 \\
$\mathrm{C} 3-\mathrm{H} 3 \cdots 3^{\mathrm{ii}}$ & 0.98 & 2.61 & $3.453(2)$ & 144 \\
$\mathrm{C} 11-\mathrm{H} 11 A \cdots \mathrm{O} 7^{\mathrm{iii}}$ & 0.96 & 2.66 & $3.329(3)$ & 127 \\
\hline
\end{tabular}

Symmetry codes: (i) $-x,-y,-z+2$; (ii) $x-1, y, z$; (iii) $x, y-1, z$.

\section{Supramolecular features}

There are two classes of identifiable non-covalent $\mathrm{C}-\mathrm{H} \cdots \mathrm{O}$ interactions occurring in the crystal of (II). As identified in PLATON (Spek, 2020), methyl-C9-H..O5(carbonyl) contacts (Table 1) occur between centrosymmetrically related molecules to form a dimeric aggregate and an 18-membered $\left\{\cdots \mathrm{OCOC}_{3} \mathrm{OCH}\right\}_{2}$ synthon, Fig. 2(a). The second level, i.e. weaker, of $\mathrm{C}-\mathrm{H} \cdots \mathrm{O}$ interactions assemble molecules into a supramolecular layer in the $a b$ plane, Fig. 2(b), at separations beyond normally accepted values in PLATON (Spek, 2020). Here, a methylene-C3-H atom is bifurcated, forming contacts with the carbonyl-O1 and O3 atoms of a translationally related molecule along the $a$-axis direction. This is complemented by a methyl-C11-H..O7(carbonyl) interaction occurring along the $b$-axis direction, Fig. 2(c). The layer thus formed by these contacts is connected into a double-layer via the methyl-C9-H. O5 (carbonyl) interactions mentioned above. The double-layers stack along the $c$ axis without directional interactions between them.

\section{Non-covalent interaction plots}

Before embarking on a more detailed analysis of the overall molecular packing of (II), in particular of the inter-layer region along the $c$ axis, non-covalent interaction plots (a)
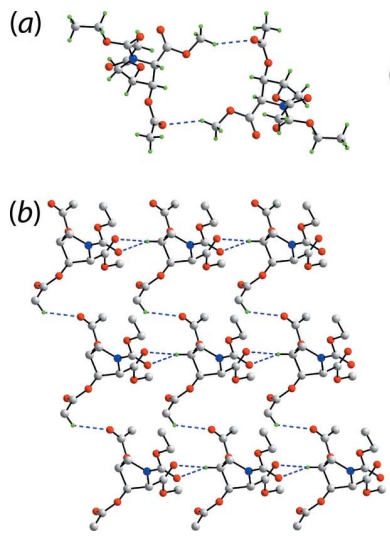

(c)

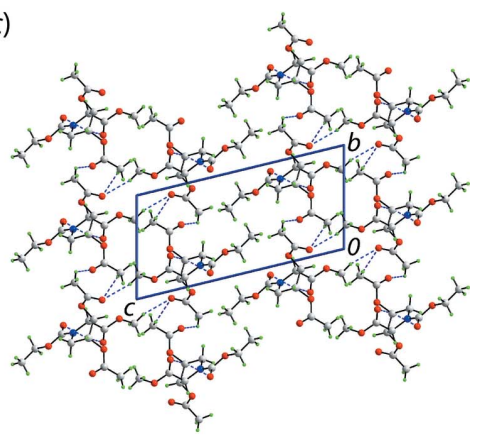

Figure 2

Molecular packing in (II): (a) supramolecular dimer sustained by methyl$\mathrm{C} 9-\mathrm{H} \cdots \mathrm{O}$ (carbonyl) contacts, (b) layer sustained by methyl-C11$\mathrm{H} \cdots \mathrm{O} 7$ (carbonyl) and bifurcated methylene-C3-H. O1,O3(carbonyl) contacts (non-participating $\mathrm{H}$ atoms are omitted) and $(c)$ a view of the unit-cell contents shown in projection down the $a$ axis. The $\mathrm{C}-\mathrm{H} \cdots \mathrm{O}$ interactions are shown as blue dashed lines. 
(a)
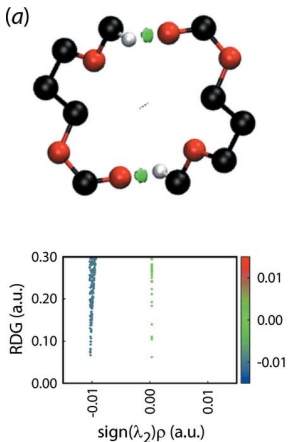

(b)
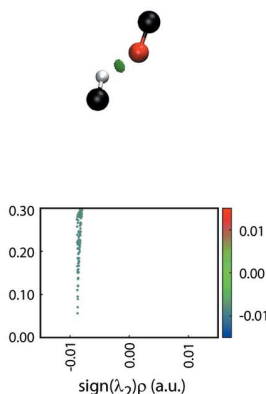

(c)
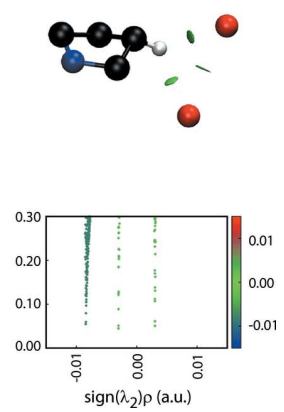

Figure 3

Non-covalent interaction plots for the following interactions in (II): (a)

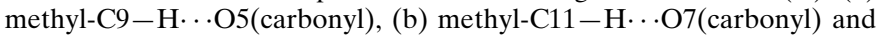

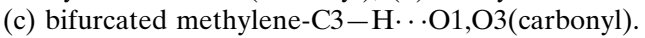

(Johnson et al., 2010; Contreras-García et al., 2011) were calculated to analyse in more detail the nature of the specified $\mathrm{C}-\mathrm{H}$... O contacts described in Supramolecular features. This method analyses the electron density (and derivatives) around the specified intermolecular contacts and generates colourbased isosurfaces as detailed in the cited literature. The results, through a three-colour scheme, enable the visualization of contacts as being attractive (blue isosurface), repulsive (red) or otherwise. For the weak interactions in focus, a green isosurface indicates a weakly attractive interaction.

The isosurfaces for three identified $\mathrm{C}-\mathrm{H}$. O O contacts are given in the upper view of Fig. 3, and each displays a green isosurface indicating weakly attractive interactions. The lower views of Fig. 3 show the plots of RDG versus $\operatorname{sign}\left(\lambda^{2}\right) \rho(r)$ for the three sets of $\mathrm{C}-\mathrm{H} \cdots \mathrm{O}$ interactions. The green peaks apparent at density values less than 0.0 a.u. indicate these are weakly attractive interactions.

(a)

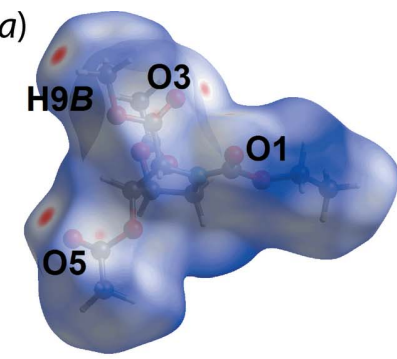

(b)
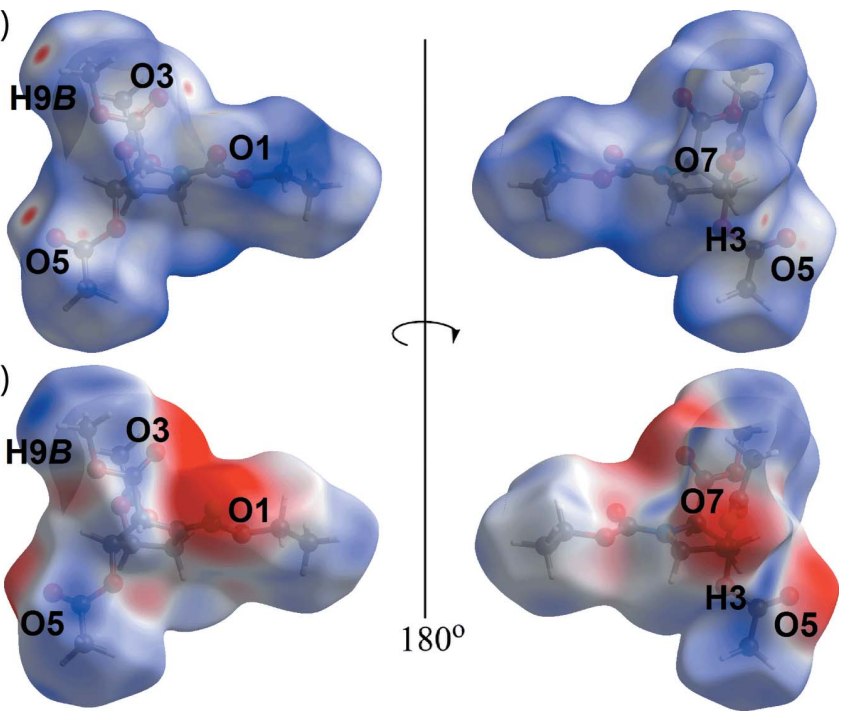

Figure 4

Two views of the Hirshfeld surface mapped for (II) over $(a) d_{\text {norm }}$ in the range of -0.083 to +1.828 arbitrary units and $(b)$ the calculated electrostatic potential in the range of -0.077 to 0.054 a.u.

\section{Hirshfeld surface analysis}

In order to understand further the interactions operating in the crystal of (II), the calculated Hirshfeld surfaces were mapped over the normalized contact distance, $d_{\text {norm }}$ (McKinnon et al., 2004) and electrostatic potential (Spackman et al., 2008) with associated two-dimensional (2-D) (full and delineated) fingerprint (FP) plots (Spackman \& McKinnon, 2002). These were generated using Crystal Explorer 17 (Turner et al., 2017) following literature procedures (Tan et al., 2019). The potentials were calculated using the STO-3G basis set at the Hartree-Fock level of theory. The bright-red spots on the Hirshfeld surface mapped over $d_{\text {norm }}$, Fig. 4(a), near the carbonyl-O (O1, O3, O5 and O7) and methyl-C- $\mathrm{H}(\mathrm{H} 3$ and $\mathrm{H} 9 B$ ) atoms correspond to the $\mathrm{C}-\mathrm{H} \cdots \mathrm{O}$ interactions listed in Table 1. These observations were confirmed through the Hirshfeld surface mapped over the calculated electrostatic potential in Fig. 4(b), where the surface around carbonyl-O and methyl- $\mathrm{C}-\mathrm{H}$ atoms are shown in red (negative electrostatic potential) and blue (positive electrostatic potential), respectively. Besides the $\mathrm{C}-\mathrm{H} \cdots \mathrm{O}$ interactions listed in Table 1, a long $\mathrm{C} 13-\mathrm{H} 13 A \cdots \mathrm{O} 5$ interaction is reflected in the $d_{\text {norm }}$ surface as a faint red spot in Fig. 5(a). In addition, short,

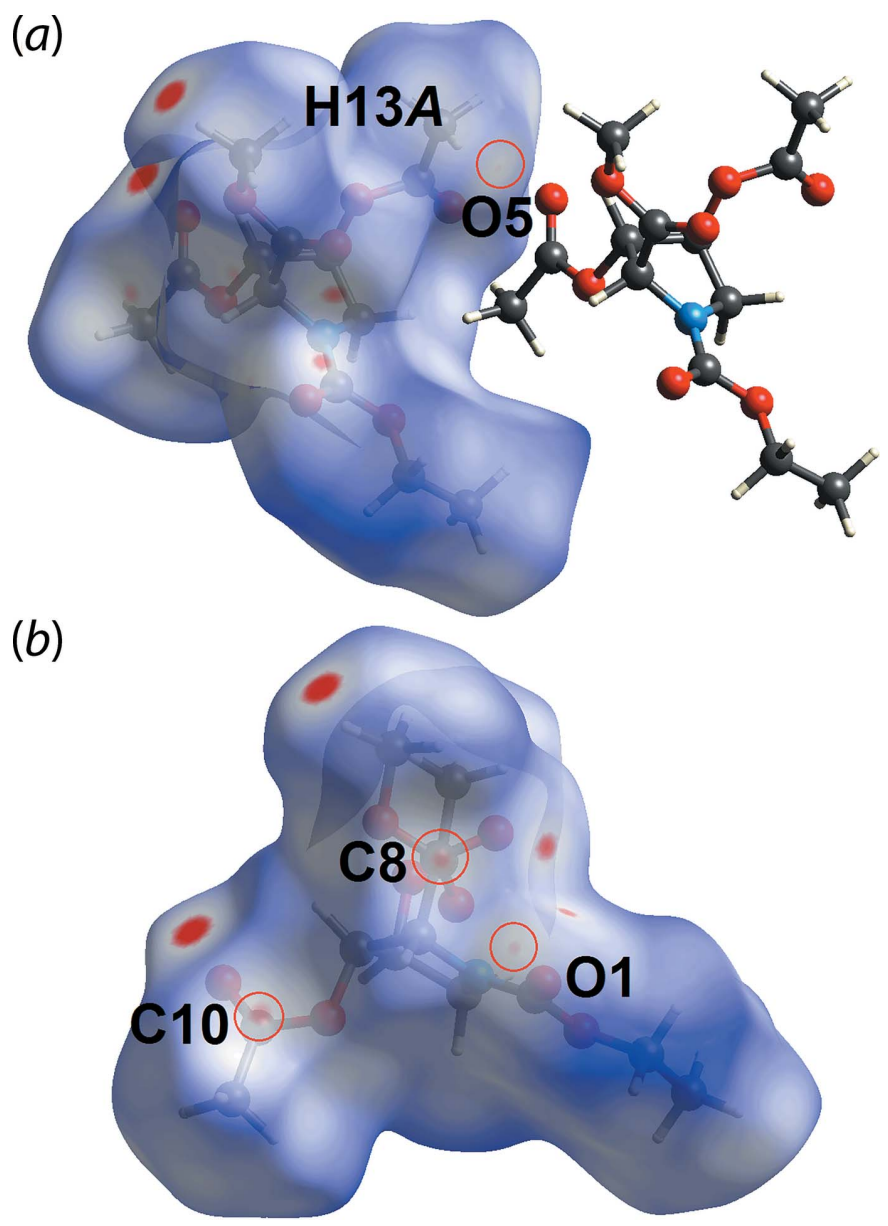

Figure 5

Views of the Hirshfeld surface mapped over $d_{\text {norm }}$ for (II) in the range -0.083 to +1.828 arbitrary units, highlighting within red circles $(a)$ a weak $\mathrm{C}-\mathrm{H} \cdots \mathrm{O}$ interaction and $(b) \mathrm{C} \cdots \mathrm{O}$ contacts. 
Table 2

Summary of short interatomic contacts $(\AA)$ in $(\mathrm{I})^{a}$.

\begin{tabular}{lll}
\hline Contact & Distance & Symmetry operation \\
\hline $\mathrm{H} 4 B \cdots \mathrm{H} 11 C$ & 2.32 & $x+1, y+1, z$ \\
$\mathrm{H} 9 B \cdots 5^{b}$ & 2.42 & $-x,-y,-z+2$ \\
$\mathrm{H} 3 \cdots \mathrm{O}^{b}$ & 2.55 & $x-1, y, z$ \\
$\mathrm{H} 3 \cdots 3^{b}$ & 2.53 & $x-1, y, z$ \\
$\mathrm{H} 11 A \cdots 7^{b}$ & 2.59 & $-x,-y+1,-z$ \\
$\mathrm{H} 13 A \cdots \mathrm{O} 5$ & 2.58 & $x+1, y+1, z$ \\
$\mathrm{C} 8 \cdots \mathrm{O} 5$ & $3.191(2)$ & $x+1, y, z$ \\
$\mathrm{C} 10 \cdots \mathrm{O} 1$ & $3.204(2)$ & $x-1, y, z$ \\
$\mathrm{C} 10 \cdots \mathrm{O} 7$ & $3.185(3)$ & $x, y-1, z$ \\
\hline
\end{tabular}

Notes: (a) The interatomic distances are calculated in Crystal Explorer 17 (Turner et al., 2017) whereby the $X-\mathrm{H}$ bond lengths are adjusted to their neutron values. (b) These interactions correspond to the interaction listed in Table 1.

intra-layer $\mathrm{C} \cdots \mathrm{O}$ contacts with separations $0.01-0.04 \AA$ shorter than the sum of their van der Waals radii, Table 2, are observed as faint red spots on the $d_{\text {norm }}$ surface in Fig. 5(b), reflecting the specific influence of the $\mathrm{C} 8, \mathrm{C} 10$ and $\mathrm{O} 1$ atoms participating in these contacts.

The corresponding two-dimensional fingerprint plot for the Hirshfeld surface of (II) is shown with characteristic pseudosymmetric wings in the upper left and lower right sides of the $d_{\mathrm{e}}$ and $d_{\mathrm{i}}$ diagonal axes, respectively, in Fig. 6(a). The individual $\mathrm{H} \cdots \mathrm{H}, \mathrm{H} \cdots \mathrm{O} / \mathrm{O} \cdots \mathrm{H}, \mathrm{H} \cdots \mathrm{C} / \mathrm{C} \cdots \mathrm{H}, \mathrm{O} \cdots \mathrm{O}, \mathrm{O} \cdots \mathrm{C} /$ $\mathrm{C} \cdots \mathrm{O}$ and $\mathrm{H} \cdots \mathrm{N} / \mathrm{N} \cdots \mathrm{H}$ contacts are illustrated in the delineated two-dimensional fingerprint plots (FP) in Fig. 6(b)- $(g)$, respectively; the percentage contributions from different interatomic contacts are summarized in Table 3 . The $\mathrm{H} \cdots \mathrm{H}$ contacts contribute $55.7 \%$ to the overall Hirshfeld surface with a beak-shape distribution in the FP with shortest $d_{\mathrm{e}}=d_{\mathrm{i}}$ $\sim 2.4 \AA$. This short interatomic $\mathrm{H} \cdots \mathrm{H}$ contact involving the methyl-H11C and methylene-H4B atoms, Table 2, is around the sum of their van der Waals separation and occurs in the intra-layer region along the $b$ axis. Consistent with the $\mathrm{C}-$ $\mathrm{H}$... O interactions making the major contribution to the directional interactions in the crystal, $\mathrm{H} \cdots \mathrm{O} / \mathrm{O} \cdots \mathrm{H}$ contacts contribute $37.0 \%$ to the overall Hirshfeld surface. A distinctive feature in the FP of Fig. 6(c), is the two symmetric spikes at $d_{\mathrm{e}}+d_{\mathrm{i}} \sim 2.4 \AA$. Although $\mathrm{H} \cdots \mathrm{C} / \mathrm{C} \cdots \mathrm{H}, \mathrm{O} \cdots \mathrm{O}, \mathrm{O} \cdots \mathrm{C} /$ $\mathrm{C} \cdots \mathrm{O}$ and $\mathrm{H} \cdots \mathrm{N} / \mathrm{N} \cdots \mathrm{H}$ appear as splash-like distributions of points at $d_{\mathrm{e}}+d_{\mathrm{i}} \sim 3.0 \AA$, Fig. $6(d)-(g)$, their contributions to the overall Hirshfeld surface are each below than $3.0 \%$. These contacts and the remaining interatomic contacts have only a small effect on the packing, as the sum of their contributions to the overall Hirshfeld surface is less than $8 \%$.

\section{Energy frameworks}

The pairwise interaction energies between the molecules in the crystal of (II) were calculated using the wave function at the B3LYP/6-31G(d,p) level of theory. The total energy comprise four terms: electrostatic $\left(E_{\mathrm{ele}}\right)$, polarization $\left(E_{\mathrm{pol}}\right)$, dispersion $\left(E_{\mathrm{dis}}\right)$ and exchange-repulsion $\left(E_{\mathrm{rep}}\right)$ and were scaled as 1.057, 0.740, 0.871 and 0.618, respectively (Edwards et al., 2017). The characteristics of the intermolecular interactions in term of their energies are collated in Table 4. In the
Table 3

Percentage contributions of interatomic contacts to the Hirshfeld surface for (II).

\begin{tabular}{ll}
\hline Contact & Percentage contribution \\
\hline $\mathrm{H} \cdots \mathrm{H}$ & 55.7 \\
$\mathrm{H} \cdots \mathrm{O} / \mathrm{O} \cdots \mathrm{H}$ & 37.0 \\
$\mathrm{H} \cdots \mathrm{C} / \mathrm{C} \cdots \mathrm{H}$ & 2.7 \\
$\mathrm{O} \cdots \mathrm{O}$ & 2.3 \\
$\mathrm{O} \cdots \mathrm{C} / \mathrm{C} \cdots \mathrm{O}$ & 1.9 \\
$\mathrm{H} \cdots \mathrm{C} / \mathrm{C} \cdots \mathrm{H}$ & 0.4 \\
\hline
\end{tabular}

absence of conventional hydrogen bonding in the crystal, the dispersive component makes the major contribution to the interaction energies (Table 4). According to the total interaction energy, molecules within the supramolecular double layer are stabilized by $\mathrm{C}-\mathrm{H} \cdots \mathrm{O}$ interaction, $\mathrm{C} \cdots \mathrm{O}$ short
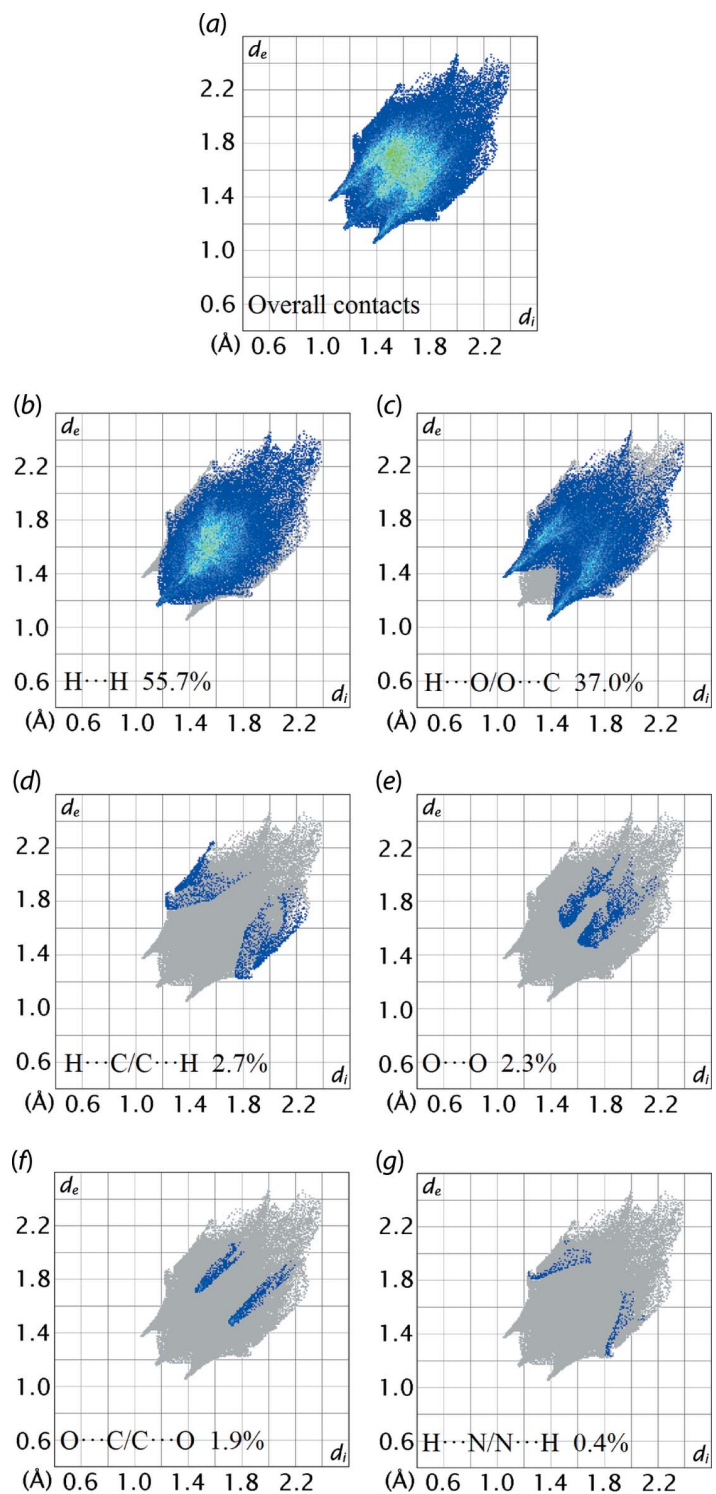

Figure 6

(a) The full two-dimensional fingerprint plot for (II) and $(b)-(g)$ those delineated into $\mathrm{H} \cdots \mathrm{H}, \mathrm{O} \cdots \mathrm{H} / \mathrm{H} \cdots \mathrm{O}, \mathrm{C} \cdots \mathrm{H} / \mathrm{H} \cdots \mathrm{C}, \mathrm{O} \cdots \mathrm{O}, \mathrm{C} \cdots \mathrm{O} /$ $\mathrm{O} \cdots \mathrm{C}$ and $\mathrm{H} \cdots \mathrm{N} / \mathrm{N} \cdots \mathrm{H}$ contacts, respectively. 

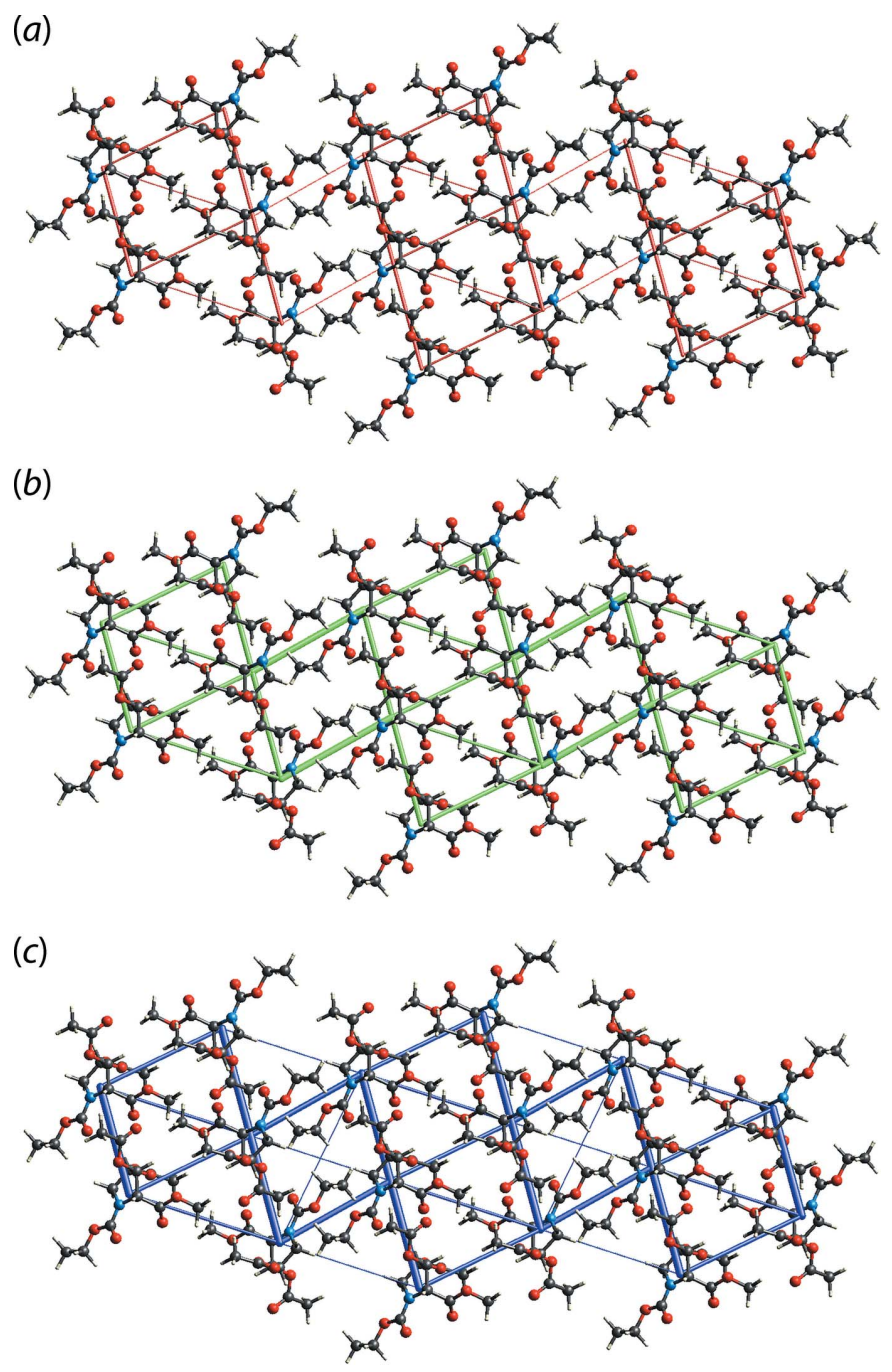

Figure 7

Perspective views of the energy frameworks calculated for (II) and viewed down the $b$ axis showing $(a)$ electrostatic potential force, $(b)$ dispersion force and (c) total energy. The radii of the cylinders are proportional to the relative magnitudes of the corresponding energies and were adjusted to the same scale factor of 55 with a cut-off value of $5 \mathrm{~kJ} \mathrm{~mol}^{-1}$ within $2 \times 2 \times 2$ unit cells.

contacts and long-range $\mathrm{H} \cdot \mathrm{H}$ contacts. Whereas molecules between the supramolecular double layers are stabilized by long-range $\mathrm{H} \cdots \mathrm{H}$ contacts. Views of the energy framework diagrams down the $b$ axis are shown in Fig. 7 and serve to emphasize the contribution of dispersion forces in the stabilization of the crystal.

\section{Database survey}

There are no close precedents for the substitution pattern observed in the tetra-substituted pyrrolidine ring of (II) with, arguably, the most closely related structure being that of (III) (KULQEP; Szcześniak et al., 2015), at least in terms of the substitution pattern around the ring; the chemical diagram for (III) is shown in Fig. 8.
Table 4

Summary of interaction energies $\left(\mathrm{kJ} \mathrm{mol}^{-1}\right)$ calculated for (II).

\begin{tabular}{|c|c|c|c|c|c|c|}
\hline Contact & $R(\AA)$ & $E_{\text {ele }}$ & $E_{\mathrm{pol}}$ & $E_{\mathrm{dis}}$ & $E_{\text {rep }}$ & $E_{\text {tot }}$ \\
\hline $\begin{array}{l}\text { Intra-double-layer } \\
\mathrm{C} 3-\mathrm{H} 3 \cdots \mathrm{O} 1^{\mathrm{ii}}+ \\
\mathrm{C} 3-\mathrm{H} 3 \cdots 3^{\mathrm{ii}}+ \\
\mathrm{O} 1 \cdots \mathrm{C} 10^{\mathrm{iv}}+\end{array}$ & & & & & & \\
\hline $\begin{array}{l}\mathrm{O} 5 \cdots \mathrm{C} 8^{\mathrm{ii}} \\
\mathrm{H} 9 B \cdots \mathrm{H} 13 C^{\mathrm{v}}+\end{array}$ & 6.8 & -19.4 & -8.3 & -33.6 & 19.3 & -44.0 \\
\hline $\begin{array}{l}\mathrm{H} 13 B \cdots \mathrm{H} 13 B^{\mathrm{v}} \\
\mathrm{C} 13-\mathrm{H} 13 A \cdots \mathrm{O} 5^{\mathrm{vi}}+ \\
\mathrm{H} 4 B \cdots \mathrm{H} 11 C^{\mathrm{vi}}+\end{array}$ & 8.2 & -5.1 & -1.6 & -28.4 & 11.0 & -24.5 \\
\hline $\begin{array}{l}\mathrm{H} 7 C \cdots \mathrm{H} 11 B^{\mathrm{vi}} \\
\mathrm{C} 11-\mathrm{H} 11 A \cdots \mathrm{O} 7^{\mathrm{iii}}+ \\
\mathrm{C} 13-\mathrm{H} 13 C \cdots \mathrm{O} 4^{\mathrm{iii}}+\end{array}$ & 9.0 & -8.8 & -2.1 & -20.8 & 10.7 & -22.4 \\
\hline $\begin{array}{l}\mathrm{C} 10 \cdots \mathrm{O} 7^{\text {vii }} \\
\mathrm{H} 9 A \cdots \cdot \mathrm{H} 13 A^{\text {viii }}+\end{array}$ & 7.9 & -8.1 & -2.9 & -20.2 & 12.5 & -20.6 \\
\hline $\mathrm{H} 9 \mathrm{C} \cdots \mathrm{H} 9 C^{\text {viii }}$ & 9.3 & -6.5 & -2.1 & -19.8 & 14.4 & $\begin{array}{l}-16.7 \\
-15.1\end{array}$ \\
\hline $\begin{array}{l}\mathrm{C} 9-\mathrm{H} 9 B \cdots \mathrm{O} 5^{\mathrm{i}} \\
\mathrm{C} 7-\mathrm{H} 7 B \cdots 7^{\mathrm{ix}}\end{array}$ & $\begin{array}{l}9.1 \\
9.9\end{array}$ & $\begin{array}{r}-10.2 \\
-3.6\end{array}$ & $\begin{array}{l}-2.3 \\
-0.9\end{array}$ & $\begin{array}{l}-12.9 \\
-15.1\end{array}$ & $\begin{array}{r}13.9 \\
4.8\end{array}$ & $\begin{array}{l}-15.1 \\
-14.7\end{array}$ \\
\hline $\begin{array}{l}\text { Inter-double-layer region } \\
\mathrm{H} 4 A \cdots \mathrm{H} 6 A^{x}+\end{array}$ & & & & & & \\
\hline $\mathrm{H} 7 B \cdots \mathrm{H} 11 B^{x}$ & 8.1 & -5.0 & -1.8 & -41.4 & 17.3 & -31.9 \\
\hline $\mathrm{H} 7 A \cdots \mathrm{H} 11 C^{\mathrm{xi}}$ & 8.9 & -0.9 & -0.4 & -10.8 & 6.2 & -6 \\
\hline
\end{tabular}

Symmetry codes: (i) $-x,-y,-z+2$; (ii) $x-1, y, z$; (iii) $x, y-1, z$; (iv) $x+1, y, z$; (v) $-x$, $-y+1,-z+2$; (vi) $x+1, y+1, z$; (vii) $x, y+1, z$; (viii) $-x+1,-y+1,-z+2$; (ix) $-x$, $-y+1,-z ;(x)-x,-y,-z+1 ;(\mathrm{xi})-x-1,-y,-z+1$.

\section{Synthesis and crystallization}

A solution of $(2 R, 3 S, 4 S)$-3,4-bis(acetyloxy)-1-(ethoxycarbonyl)pyrrolidine-2-carboxylic acid $(40 \mathrm{mg}, 0.132 \mathrm{mmol})$ in methanol $(1 \mathrm{ml})$ was cooled to $273-278 \mathrm{~K}$ after which an excess of a cold, freshly prepared solution of $\mathrm{CH}_{2} \mathrm{~N}_{2}$ in ether was added. The mixture was stirred at room temperature for 10 min. Excess $\mathrm{CH}_{2} \mathrm{~N}_{2}$ was eliminated by purging the balloon with a dry air flow. The purge was collected on a solution of $\mathrm{HOAc}$ in $\mathrm{MeOH}$. The reaction solution was concentrated to dryness and the residue was purified by flash column chromatography on silica gel, using a mixture of EtOAc/n-hexane (1:3). Yield: $41.7 \mathrm{mg}$ (quantitative) of (II). Colourless irregular crystals for the X-ray analysis were obtained by the slow evaporation of its $n$-hexane solution. M.p. 347.6-348.7 K.

The ${ }^{1} \mathrm{H}$ and ${ }^{13} \mathrm{C}$ NMR reflect the presence of two conformational rotamers in solution. ${ }^{1} \mathrm{H}$ NMR $\left(500 \mathrm{MHz}, \mathrm{CDCl}_{3}\right): \delta$ $=5.38\left(s, 1 \mathrm{H}, \mathrm{H}_{3}\right) ; 5.11\left(s, 1 \mathrm{H}, \mathrm{H}_{4}\right) ; 4.51$ and $4.42\left(2 s, 1 \mathrm{H}, \mathrm{H}_{2}\right)$; 4.23-4.05 (2m, 2H, $\left.\mathrm{CH}_{2} \mathrm{CH}_{3}\right) ; 3.91$ and $3.87(2 d d, J=12.8 \mathrm{~Hz}$ and $\left.5.5 \mathrm{~Hz}, 1 \mathrm{H}, \mathrm{H}_{4 \mathrm{a}}\right) ; 3.772$ and $3.766\left(2 \mathrm{~s}, 3 \mathrm{H}, \mathrm{CO}_{2} \mathrm{CH}_{3}\right) ; 3.63$

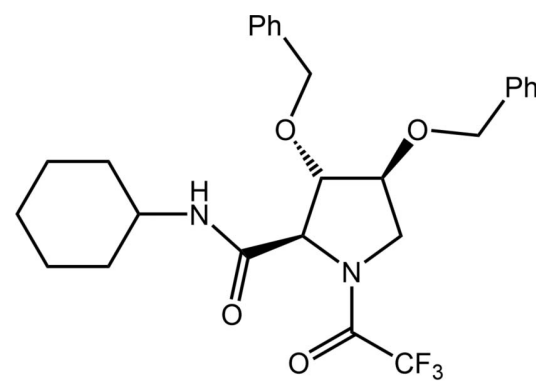

Figure 8 (III) 
and $3.59\left(2 d, J=12.8 \mathrm{~Hz}, 1 \mathrm{H}, \mathrm{H}_{4 \mathrm{~b}}\right) ; 2.10$ and 2.09 (2s, 3H, Ac); 2.01 and $2.00(2 s, 3 \mathrm{H}, \mathrm{Ac}) ; 1.28$ and $1.21(2 t, J=7.0 \mathrm{~Hz}, 3 \mathrm{H}$, $\left.\mathrm{CH}_{2} \mathrm{CH}_{3}\right) .{ }^{1} \mathrm{H}$ NMR $\left(500 \mathrm{MHz}, \mathrm{C}_{6} \mathrm{D}_{6}\right.$, r.t.): $\delta=5.62\left(s, 1 \mathrm{H}, \mathrm{H}_{3}\right)$; 5.07 and $5.02\left(2 a p t, J=2.7 \mathrm{~Hz}, 1 \mathrm{H}, \mathrm{H}_{3}\right) ; 4.78\left(s, 0.6 \mathrm{H}, \mathrm{H}_{1}\right) ; 4.55$ $\left(s, 0.4 \mathrm{H}, \mathrm{H}_{1}\right) ; 4.12$ and $4.10\left(2 q, J=7.0 \mathrm{~Hz}, 0.4 \mathrm{H}, \mathrm{CH}_{2} \mathrm{CH}_{3}\right)$; 4.01-3.88 $\left(q+m, J=7.0 \mathrm{~Hz}, 2 \mathrm{H}, \mathrm{CH}_{2} \mathrm{CH}_{3}\right.$ and $\left.\mathrm{H}_{4 \mathrm{a}}\right) ; 3.84-3.76$ $\left(m, 1 \mathrm{H}, \mathrm{H}_{4 \mathrm{~b}}\right) ; 3.65\left(d d, J=12.2 \mathrm{~Hz}\right.$ and $\left.2.4 \mathrm{~Hz}, 0.6 \mathrm{H}, \mathrm{H}_{4 \mathrm{a}}\right) ; 3.31$ and $3.30\left(2 s, 3 \mathrm{H}, \mathrm{CO}_{2} \mathrm{CH}_{3}\right) ; 1.48$ and 1.45 (2s, 3H, Ac); 1.43 and $1.42(2 s, 3 \mathrm{H}, \mathrm{Ac}) ; 0.94$ and $0.92(2 t, J=7.0 \mathrm{~Hz}, 3 \mathrm{H}$, $\left.\mathrm{CH}_{2} \mathrm{CH}_{3}\right) .{ }^{13} \mathrm{C}$ NMR $\left(125 \mathrm{MHz}, \mathrm{CDCl}_{3}\right.$, r.t.): $\delta=169.4 ; 169.3$; $169.2 ; 168.8 ; 168.7 ; 154.8 ; 154.4 ; 77.9 ; 76.9 ; 74.5 ; 73.5 ; 63.6 ; 63.5$; $61.9 ; 61.7 ; 52.7 ; 52.6 ; 50.6 ; 50.4 ; 20.74 ; 20.70 ; 20.65 ; 14.5$. Microanalysis calculated for $\mathrm{C}_{13} \mathrm{H}_{19} \mathrm{NO}_{8}$ : C 49.21, $\mathrm{H} 6.04, \mathrm{~N}$ $4.41 \%$. Found: C 48.89, H 6.52, N 4.50\%.

\section{Refinement details}

Crystal data, data collection and structure refinement details are summarized in Table 5. The carbon-bound $\mathrm{H}$ atoms were placed in calculated positions $(\mathrm{C}-\mathrm{H}=0.96-0.98 \AA)$ and were included in the refinement in the riding-model approximation, with $U_{\text {iso }}(\mathrm{H})$ set to $1.2-1.5 U_{\text {eq }}(\mathrm{C})$.

\section{Funding information}

The Brazilian agencies Coordination for the Improvement of Higher Education Personnel, CAPES, Finance Code 001 and the National Council for Scientific and Technological Development (CNPq) are acknowledged for grants (312210/2019-1, 433957/2018-2 and 406273/2015-4) to IC, for a fellowship (303207/2017-5) to JZS and a scholarship to SDP. Sunway University Sdn Bhd is also thanked for funding (grant. No. STR-RCTR-RCCM-001-2019).

\section{References}

Assefa, S. T., Yang, E.-Y., Chae, S.-Y., Song, M., Lee, J., Cho, M.-C. \& Jang, S. (2020). Plants, 9 article No. 2.

Brandenburg, K. (2006). DIAMOND. Crystal Impact GbR, Bonn, Germany.

Brás, N. F., Cerqueira, N. M. F. S. A., Ramos, M. J. \& Fernandes, P. A. (2014). Expert Opin. Ther. Pat. 24, 857-874.

Burla, M. C., Caliandro, R., Carrozzini, B., Cascarano, G. L., Cuocci, C., Giacovazzo, C., Mallamo, M., Mazzone, A. \& Polidori, G. (2015). J. Appl. Cryst. 48, 306-309.

ChemAxon (2010). MarvinSketch. http://www.chemaxon.com.

Contreras-García, J., Johnson, E. R., Keinan, S., Chaudret, R., Piquemal, J.-P., Beratan, D. N. \& Yang, W. (2011). J. Chem. Theory Comput. 7, 625-632.

Dhameja, M. \& Gupta, P. (2019). Eur. J. Med. Chem. 176 article No. $343 \mathrm{e} 377$.

Edwards, A. J., Mackenzie, C. F., Spackman, P. R., Jayatilaka, D. \& Spackman, M. A. (2017). Faraday Discuss. 203, 93-112.

Enraf Nonius (1989). CAD-4 EXPRESS. Enraf-Nonius, Delft, The Netherlands.

Farrugia, L. J. (2012). J. Appl. Cryst. 45, 849-854.

Garcia, A. L. L. (2008). PhD thesis, Universidade Estadual de Campinas, UNICAMP, Campinas, SP, Brazil.
Table 5

Experimental details.

Crystal data

Chemical formula

$M_{\mathrm{r}}$

Crystal system, space group

Temperature (K)

$a, b, c(\AA)$

$\alpha, \beta, \gamma\left({ }^{\circ}\right)$

$V\left(\AA^{3}\right)$

$Z$

Radiation type

$\mu\left(\mathrm{mm}^{-1}\right)$

Crystal size (mm)

$\mathrm{C}_{13} \mathrm{H}_{19} \mathrm{NO}_{8}$
317.29
Triclinic, $P \overline{1}$
290
$6.8291(5), 7.8670(11), 15.814(3)$
$100.607(11), 99.011(10)$,
$\quad 105.054(7)$
$787.5(2)$
2
Mo $K \alpha$
0.11
$0.40 \times 0.35 \times 0.10$

Data collection

Diffractometer

No. of measured, independent and observed $[I>2 \sigma(I)]$ reflections

$R_{\text {int }}$

$(\sin \theta / \lambda)_{\max }\left(\AA^{-1}\right)$

Enraf Nonius TurboCAD-4 $4880,4573,2571$

0.020

0.703

\section{Refinement}

$R\left[F^{2}>2 \sigma\left(F^{2}\right)\right], w R\left(F^{2}\right), S \quad 0.042,0.128,0.99$

No. of reflections

No. of parameters

$\mathrm{H}$-atom treatment

$\Delta \rho_{\max }, \Delta \rho_{\min }\left(\mathrm{e} \AA^{-3}\right)$

4573

203

H-atom parameters constrained $0.18,-0.17$

Computer programs: CAD-4 EXPRESS (Enraf Nonius, 1989), XCAD4 (Harms \& Wocadlo, 1995), SIR2014 (Burla et al., 2015), SHELXL2018/3 (Sheldrick, 2015), ORTEP3 for Windows (Farrugia, 2012), MarvinSketch (ChemAxon, 2010), DIAMOND (Brandenburg, 2006) and publCIF (Westrip, 2010).

Harms, K. \& Wocadlo, S. (1995). XCAD4. University of Marburg, Germany.

Johnson, E. R., Keinan, S., Mori-Sánchez, P., Contreras-García, J., Cohen, A. J. \& Yang, W. (2010). J. Am. Chem. Soc. 132, 64986506.

Kiappes, J. L., Hill, M. L., Alonzi, D. S., Miller, J. L., Iwaki, R., Sayce, A. C., Caputo, A. T., Kato, A. \& Zitzmann, N. (2018). Chem. Biol. 13, 60-65.

Liu, Z. \& Ma, S. (2017). ChemMedChem, 12, 819-829.

Matassini, C., Warren, J., Wang, B., Goti, A., Cardona, F., Morrone, A. \& Bols, M. (2020). Angew. Chem. Int. Ed. 59 https://doi.org/10.1002/ anie. 202002850

McKinnon, J. J., Spackman, M. A. \& Mitchell, A. S. (2004). Acta Cryst. B60, 627-668.

Sheldrick, G. M. (2015). Acta Cryst. C71, 3-8.

Spackman, M. A. \& McKinnon, J. J. (2002). CrystEngComm, 4, 378392.

Spackman, M. A., McKinnon, J. J. \& Jayatilaka, D. (2008). CrystEngComm, 10, 377-388.

Spek, A. L. (2020). Acta Cryst. E76, 1-11.

Szcześniak, P., Maziarz, E., Stecko, S. \& Furman, B. (2015). J. Org. Chem. 80, 3621-3633.

Tan, S. L., Jotani, M. M. \& Tiekink, E. R. T. (2019). Acta Cryst. E75, 308-318.

Turner, M. J., Mckinnon, J. J., Wolff, S. K., Grimwood, D. J., Spackman, P. R., Jayatilaka, D. \& Spackman, M. A. (2017). Crystal Explorer 17. The University of Western Australia.

Westrip, S. P. (2010). J. Appl. Cryst. 43, 920-925.

Zukerman-Schpector, J., Sugiyama, F. H., Garcia, A. L. L., Correia, C. R. D., Jotani, M. M. \& Tiekink, E. R. T. (2017). Acta Cryst. E73, $1218-1222$. 


\section{supporting information}

Acta Cryst. (2020). E76, 967-972 [https://doi.org/10.1107/S205698902000701X]

\section{1-Ethyl 2-methyl 3,4-bis(acetyloxy)pyrrolidine-1,2-dicarboxylate: crystal structure, Hirshfeld surface analysis and computational chemistry}

Sofia Dallasta Pedroso, Ignez Caracelli, Julio Zukerman-Schpector, Monica Soto-Monsalve, Regina H. De Almeida Santos, Carlos Roque D. Correia, Ariel L. Llanes Garcia, Huey Chong Kwong and Edward R. T. Tiekink

Computing details

Data collection: CAD-4 EXPRESS (Enraf Nonius, 1989); cell refinement: CAD-4 EXPRESS (Enraf Nonius, 1989); data reduction: XCAD4 (Harms \& Wocadlo, 1995); program(s) used to solve structure: SIR2014 (Burla et al., 2015); program(s) used to refine structure: SHELXL2018/3 (Sheldrick, 2015); molecular graphics: ORTEP-3 for Windows (Farrugia, 2012), MarvinSketch (ChemAxon, 2010) and DIAMOND (Brandenburg, 2006); software used to prepare material for publication: publCIF (Westrip, 2010).

1-Ethyl 2-methyl 3,4-bis(acetyloxy)pyrrolidine-1,2-dicarboxylate

Crystal data

$\mathrm{C}_{13} \mathrm{H}_{19} \mathrm{NO}_{8}$

$M_{r}=317.29$

Triclinic, $P \overline{1}$

$a=6.8291(5) \AA$

$b=7.8670$ (11) $\AA$

$c=15.814(3) \AA$

$\alpha=100.607(11)^{\circ}$

$\beta=99.011(10)^{\circ}$

$\gamma=105.054(7)^{\circ}$

$V=787.5(2) \AA^{3}$

Data collection

Enraf Nonius TurboCAD-4 diffractometer

Radiation source: Enraf Nonius FR590

non-profiled $\omega / 2 \theta$ scans

4880 measured reflections

4573 independent reflections

2571 reflections with $I>2 \sigma(I)$

Refinement

Refinement on $F^{2}$

Least-squares matrix: full

$R\left[F^{2}>2 \sigma\left(F^{2}\right)\right]=0.042$

$w R\left(F^{2}\right)=0.128$

$S=0.99$
$Z=2$

$F(000)=336$

$D_{\mathrm{x}}=1.338 \mathrm{Mg} \mathrm{m}^{-3}$

Mo $K \alpha$ radiation, $\lambda=0.71073 \AA$

Cell parameters from 25 reflections

$\theta=10.8-18.2^{\circ}$

$\mu=0.11 \mathrm{~mm}^{-1}$

$T=290 \mathrm{~K}$

Irregular, colourless

$0.40 \times 0.35 \times 0.10 \mathrm{~mm}$

$R_{\text {int }}=0.020$

$\theta_{\max }=30.0^{\circ}, \theta_{\min }=2.7^{\circ}$

$h=-9 \rightarrow 9$

$k=0 \rightarrow 11$

$l=-22 \rightarrow 21$

3 standard reflections every $120 \mathrm{~min}$

intensity decay: $2 \%$

4573 reflections

203 parameters

0 restraints

Primary atom site location: structure-invariant direct methods 
Secondary atom site location: difference Fourier map

Hydrogen site location: inferred from neighbouring sites

$\mathrm{H}$-atom parameters constrained

$$
\begin{aligned}
& w=1 /\left[\sigma^{2}\left(F_{\mathrm{o}}^{2}\right)+(0.0579 P)^{2}+0.0763 P\right] \\
& \text { where } P=\left(F_{\mathrm{o}}^{2}+2 F_{\mathrm{c}}{ }^{2}\right) / 3 \\
& (\Delta / \sigma)_{\max }=0.001 \\
& \Delta \rho_{\max }=0.18 \mathrm{e} \AA^{-3} \\
& \Delta \rho_{\min }=-0.17 \mathrm{e} \AA^{-3}
\end{aligned}
$$

Special details

Geometry. All esds (except the esd in the dihedral angle between two 1.s. planes) are estimated using the full covariance

\begin{tabular}{|c|c|c|c|c|}
\hline & $x$ & $y$ & $z$ & $U_{\text {iso }} * / U_{\text {eq }}$ \\
\hline $\mathrm{O} 1$ & $0.28490(19)$ & 0.08131 (19) & $0.64555(9)$ & $0.0568(3)$ \\
\hline $\mathrm{O} 2$ & $0.12213(18)$ & $0.24723(18)$ & $0.57354(8)$ & $0.0513(3)$ \\
\hline $\mathrm{O} 3$ & $0.35221(19)$ & $0.33818(18)$ & $0.83767(9)$ & $0.0586(3)$ \\
\hline $\mathrm{O} 4$ & $0.20434(18)$ & $0.14935(17)$ & $0.91551(8)$ & $0.0504(3)$ \\
\hline O5 & $-0.5275(2)$ & $-0.0729(2)$ & $0.83254(9)$ & $0.0662(4)$ \\
\hline O6 & $-0.32790(16)$ & $-0.06328(15)$ & $0.73314(7)$ & $0.0424(3)$ \\
\hline $\mathrm{O} 7$ & $-0.2014(3)$ & $0.6135(2)$ & $0.78612(11)$ & $0.0753(4)$ \\
\hline $\mathrm{O} 8$ & $-0.08692(17)$ & $0.40628(15)$ & $0.84074(7)$ & $0.0426(3)$ \\
\hline N1 & $0.0250(2)$ & $0.1764(2)$ & $0.69258(9)$ & 0.0433 \\
\hline $\mathrm{C} 1$ & $0.0322(2)$ & $0.0990(2)$ & $0.76913(10)$ & $0.0372(3)$ \\
\hline H1 & 0.041065 & -0.024702 & 0.752792 & $0.045 *$ \\
\hline $\mathrm{C} 2$ & $-0.1782(2)$ & $0.0948(2)$ & $0.79177(10)$ & $0.0357(3)$ \\
\hline $\mathrm{H} 2$ & -0.177363 & 0.096071 & 0.853908 & $0.043 *$ \\
\hline $\mathrm{C} 3$ & $-0.2178(2)$ & $0.2626(2)$ & $0.76694(10)$ & 0.0388 \\
\hline $\mathrm{H} 3$ & -0.364464 & 0.257939 & 0.758613 & $0.047 *$ \\
\hline $\mathrm{C} 4$ & $-0.1353(2)$ & $0.2683(2)$ & $0.68313(11)$ & $0.0430(4)$ \\
\hline $\mathrm{H} 4 \mathrm{~A}$ & -0.244190 & 0.204920 & 0.631224 & $0.052 *$ \\
\hline H4B & -0.076679 & 0.392201 & 0.679209 & $0.052 *$ \\
\hline $\mathrm{C} 5$ & $0.1565(2)$ & $0.1615(2)$ & $0.63798(10)$ & $0.0424(4)$ \\
\hline C6 & 0.2518 & 0.2410 & $0.50973(13)$ & $0.0631(5)$ \\
\hline H6A & 0.234590 & 0.116529 & 0.480776 & $0.076^{*}$ \\
\hline H6B & 0.396809 & 0.298206 & 0.538377 & $0.076^{*}$ \\
\hline C7 & $0.1853(4)$ & $0.3399(4)$ & $0.44469(15)$ & $0.0818(7)$ \\
\hline $\mathrm{H} 7 \mathrm{~A}$ & 0.041201 & 0.282919 & 0.417435 & $0.123^{*}$ \\
\hline H7B & 0.266749 & 0.337723 & 0.400460 & $0.123^{*}$ \\
\hline $\mathrm{H} 7 \mathrm{C}$ & 0.204764 & 0.463198 & 0.474089 & $0.123^{*}$ \\
\hline $\mathrm{C} 8$ & $0.2155(2)$ & $0.2132(2)$ & $0.84352(11)$ & $0.0404(3)$ \\
\hline C9 & $0.3834(3)$ & $0.2283(4)$ & $0.98760(14)$ & $0.0766(7)$ \\
\hline H9A & 0.506912 & 0.224946 & 0.966399 & $0.115^{*}$ \\
\hline H9B & 0.370682 & 0.160845 & 1.032257 & $0.115^{*}$ \\
\hline $\mathrm{H} 9 \mathrm{C}$ & 0.391528 & 0.351722 & 1.012025 & $0.115^{*}$ \\
\hline $\mathrm{C} 10$ & $-0.4972(2)$ & $-0.1374(2)$ & $0.76304(12)$ & $0.0461(4)$ \\
\hline C11 & $-0.6347(3)$ & $-0.3050(3)$ & $0.69971(16)$ & $0.0697(6)$ \\
\hline H11A & -0.581462 & -0.404559 & 0.706145 & $0.104 *$ \\
\hline
\end{tabular}
matrix. The cell esds are taken into account individually in the estimation of esds in distances, angles and torsion angles; correlations between esds in cell parameters are only used when they are defined by crystal symmetry. An approximate (isotropic) treatment of cell esds is used for estimating esds involving l.s. planes.

Fractional atomic coordinates and isotropic or equivalent isotropic displacement parameters $\left(\AA^{2}\right)$ 


\begin{tabular}{lllll} 
H11B & -0.639848 & -0.289168 & 0.640732 & $0.104^{*}$ \\
H11C & -0.771979 & -0.329842 & 0.711270 & $0.104^{*}$ \\
C12 & $-0.0926(3)$ & $0.5768(2)$ & $0.84243(13)$ & $0.0500(4)$ \\
C13 & $0.0585(4)$ & $0.7066(3)$ & $0.92107(15)$ & $0.0696(6)$ \\
H13A & 0.194942 & 0.735689 & 0.908739 & $0.104^{*}$ \\
H13B & 0.058933 & 0.652183 & 0.970653 & $0.104^{*}$ \\
H13C & 0.018502 & 0.815216 & 0.934292 & $0.104^{*}$ \\
\hline
\end{tabular}

Atomic displacement parameters $\left(\AA^{2}\right)$

\begin{tabular}{|c|c|c|c|c|c|c|}
\hline & $U^{11}$ & $U^{22}$ & $U^{33}$ & $U^{12}$ & $U^{13}$ & $U^{23}$ \\
\hline $\mathrm{O} 1$ & $0.0482(7)$ & $0.0740(9)$ & $0.0610(8)$ & $0.0303(7)$ & $0.0206(6)$ & $0.0223(7)$ \\
\hline $\mathrm{O} 2$ & $0.0509(7)$ & $0.0668(8)$ & $0.0457(6)$ & $0.0205(6)$ & $0.0212(5)$ & $0.0231(6)$ \\
\hline $\mathrm{O} 3$ & $0.0431(6)$ & $0.0550(8)$ & $0.0714(8)$ & $0.0012(6)$ & $0.0106(6)$ & $0.0205(7)$ \\
\hline $\mathrm{O} 4$ & $0.0476(6)$ & $0.0545(7)$ & $0.0462(6)$ & $0.0117(6)$ & $0.0003(5)$ & $0.0186(6)$ \\
\hline O5 & $0.0573(8)$ & $0.0702(10)$ & $0.0703(9)$ & $0.0073(7)$ & $0.0301(7)$ & $0.0171(8)$ \\
\hline O6 & $0.0357(5)$ & $0.0405(6)$ & $0.0475(6)$ & $0.0065(5)$ & $0.0088(5)$ & $0.0092(5)$ \\
\hline $\mathrm{O} 7$ & $0.0854(11)$ & $0.0571(9)$ & 0.0929 (11) & $0.0370(8)$ & $0.0070(9)$ & $0.0284(8)$ \\
\hline O8 & $0.0440(6)$ & $0.0367(6)$ & $0.0497(6)$ & $0.0151(5)$ & $0.0096(5)$ & $0.0122(5)$ \\
\hline N1 & $0.0395(7)$ & $0.0576(9)$ & $0.0448(7)$ & $0.0230(6)$ & $0.0144(6)$ & $0.0243(6)$ \\
\hline $\mathrm{C} 1$ & $0.0345(7)$ & $0.0403(8)$ & $0.0423(8)$ & $0.0148(6)$ & $0.0098(6)$ & $0.0168(7)$ \\
\hline $\mathrm{C} 2$ & $0.0327(7)$ & $0.0348(8)$ & $0.0397(8)$ & $0.0087(6)$ & $0.0082(6)$ & $0.0105(6)$ \\
\hline $\mathrm{C} 3$ & $0.0322(7)$ & $0.0404(8)$ & $0.0458(8)$ & $0.0125(6)$ & $0.0082(6)$ & $0.0127(7)$ \\
\hline $\mathrm{C} 4$ & $0.0411(8)$ & $0.0497(10)$ & $0.0446(8)$ & $0.0186(7)$ & $0.0094(7)$ & $0.0196(7)$ \\
\hline $\mathrm{C} 5$ & $0.0359(7)$ & $0.0520(10)$ & $0.0389(8)$ & $0.0111(7)$ & $0.0086(6)$ & $0.0118(7)$ \\
\hline C6 & $0.0635(12)$ & $0.0808(15)$ & $0.0527(11)$ & 0.0219 (11) & $0.0292(9)$ & $0.0195(10)$ \\
\hline $\mathrm{C} 7$ & $0.0946(17)$ & $0.112(2)$ & $0.0566(12)$ & $0.0356(15)$ & $0.0357(12)$ & 0.0387 (13) \\
\hline $\mathrm{C} 8$ & $0.0357(7)$ & $0.0424(9)$ & $0.0477(9)$ & $0.0155(7)$ & $0.0101(6)$ & $0.0154(7)$ \\
\hline $\mathrm{C} 9$ & $0.0645(13)$ & $0.0948(18)$ & $0.0570(12)$ & $0.0172(12)$ & $-0.0142(10)$ & $0.0169(12)$ \\
\hline $\mathrm{C} 10$ & $0.0358(8)$ & $0.0443(9)$ & $0.0596(10)$ & $0.0088(7)$ & $0.0106(7)$ & $0.0200(8)$ \\
\hline C11 & $0.0448(10)$ & $0.0558(12)$ & 0.0917 (16) & $-0.0003(9)$ & $0.0043(10)$ & $0.0075(11)$ \\
\hline $\mathrm{C} 12$ & $0.0516(9)$ & $0.0402(9)$ & $0.0677(12)$ & $0.0181(8)$ & $0.0229(9)$ & $0.0213(9)$ \\
\hline $\mathrm{C} 13$ & $0.0803(14)$ & $0.0425(11)$ & $0.0764(14)$ & $0.0050(10)$ & $0.0192(12)$ & $0.0075(10)$ \\
\hline
\end{tabular}

Geometric parameters $\left(\AA,{ }^{\circ}\right)$

\begin{tabular}{llll}
\hline $\mathrm{O} 1-\mathrm{C} 5$ & $1.2098(19)$ & $\mathrm{C} 3-\mathrm{H} 3$ & 0.9800 \\
$\mathrm{O} 2-\mathrm{C} 5$ & $1.345(2)$ & $\mathrm{C} 4-\mathrm{H} 4 \mathrm{~A}$ & 0.9700 \\
$\mathrm{O} 2-\mathrm{C} 6$ & $1.446(2)$ & $\mathrm{C} 4-\mathrm{H} 4 \mathrm{~B}$ & 0.9700 \\
$\mathrm{O} 3-\mathrm{C} 8$ & $1.1961(19)$ & $\mathrm{C} 6-\mathrm{C} 7$ & $1.484(3)$ \\
$\mathrm{O} 4-\mathrm{C} 8$ & $1.3312(19)$ & $\mathrm{C} 6-\mathrm{H} 6 \mathrm{~A}$ & 0.9700 \\
$\mathrm{O} 4-\mathrm{C} 9$ & $1.445(2)$ & $\mathrm{C} 6-\mathrm{H} 6 \mathrm{~B}$ & 0.9700 \\
$\mathrm{O} 5-\mathrm{C} 10$ & $1.195(2)$ & $\mathrm{C} 7-\mathrm{H} 7 \mathrm{~A}$ & 0.9600 \\
$\mathrm{O} 6-\mathrm{C} 10$ & $1.3499(19)$ & $\mathrm{C} 7-\mathrm{H} 7 \mathrm{~B}$ & 0.9600 \\
$\mathrm{O} 6-\mathrm{C} 2$ & $1.4385(18)$ & $\mathrm{C} 7-\mathrm{H} 7 \mathrm{C}$ & 0.9600 \\
$\mathrm{O} 7-\mathrm{C} 12$ & $1.195(2)$ & $\mathrm{C} 9-\mathrm{H} 9 \mathrm{~A}$ & 0.9600 \\
$\mathrm{O} 8-\mathrm{C} 12$ & $1.348(2)$ & $\mathrm{C} 9-\mathrm{H} 9 \mathrm{~B}$ & 0.9600 \\
$\mathrm{O} 8-\mathrm{C} 3$ & $1.4496(19)$ & $\mathrm{C} 9-\mathrm{H} 9 \mathrm{C}$ & 0.9600
\end{tabular}




\begin{tabular}{|c|c|c|c|}
\hline $\mathrm{N} 1-\mathrm{C} 5$ & $1.351(2)$ & $\mathrm{C} 10-\mathrm{C} 11$ & $1.483(3)$ \\
\hline $\mathrm{N} 1-\mathrm{C} 1$ & $1.4518(19)$ & $\mathrm{C} 11-\mathrm{H} 11 \mathrm{~A}$ & 0.9600 \\
\hline $\mathrm{N} 1-\mathrm{C} 4$ & $1.464(2)$ & C11-H11B & 0.9600 \\
\hline $\mathrm{C} 1-\mathrm{C} 8$ & $1.524(2)$ & $\mathrm{C} 11-\mathrm{H} 11 \mathrm{C}$ & 0.9600 \\
\hline $\mathrm{C} 1-\mathrm{C} 2$ & $1.528(2)$ & $\mathrm{C} 12-\mathrm{C} 13$ & $1.496(3)$ \\
\hline $\mathrm{C} 1-\mathrm{H} 1$ & 0.9800 & $\mathrm{C} 13-\mathrm{H} 13 \mathrm{~A}$ & 0.9600 \\
\hline $\mathrm{C} 2-\mathrm{C} 3$ & $1.521(2)$ & $\mathrm{C} 13-\mathrm{H} 13 \mathrm{~B}$ & 0.9600 \\
\hline $\mathrm{C} 2-\mathrm{H} 2$ & 0.9800 & $\mathrm{C} 13-\mathrm{H} 13 \mathrm{C}$ & 0.9600 \\
\hline $\mathrm{C} 3-\mathrm{C} 4$ & $1.523(2)$ & & \\
\hline $\mathrm{C} 5-\mathrm{O} 2-\mathrm{C} 6$ & $115.92(14)$ & $\mathrm{O} 2-\mathrm{C} 6-\mathrm{H} 6 \mathrm{~B}$ & 110.4 \\
\hline $\mathrm{C} 8-\mathrm{O} 4-\mathrm{C} 9$ & $115.73(15)$ & $\mathrm{C} 7-\mathrm{C} 6-\mathrm{H} 6 \mathrm{~B}$ & 110.4 \\
\hline $\mathrm{C} 10-\mathrm{O} 6-\mathrm{C} 2$ & $116.20(12)$ & $\mathrm{H} 6 \mathrm{~A}-\mathrm{C} 6-\mathrm{H} 6 \mathrm{~B}$ & 108.6 \\
\hline $\mathrm{C} 12-\mathrm{O} 8-\mathrm{C} 3$ & $118.19(13)$ & $\mathrm{C} 6-\mathrm{C} 7-\mathrm{H} 7 \mathrm{~A}$ & 109.5 \\
\hline $\mathrm{C} 5-\mathrm{N} 1-\mathrm{C} 1$ & $121.34(13)$ & $\mathrm{C} 6-\mathrm{C} 7-\mathrm{H} 7 \mathrm{~B}$ & 109.5 \\
\hline $\mathrm{C} 5-\mathrm{N} 1-\mathrm{C} 4$ & $125.77(13)$ & $\mathrm{H} 7 \mathrm{~A}-\mathrm{C} 7-\mathrm{H} 7 \mathrm{~B}$ & 109.5 \\
\hline $\mathrm{C} 1-\mathrm{N} 1-\mathrm{C} 4$ & $112.89(12)$ & $\mathrm{C} 6-\mathrm{C} 7-\mathrm{H} 7 \mathrm{C}$ & 109.5 \\
\hline $\mathrm{N} 1-\mathrm{C} 1-\mathrm{C} 8$ & $111.47(13)$ & $\mathrm{H} 7 \mathrm{~A}-\mathrm{C} 7-\mathrm{H} 7 \mathrm{C}$ & 109.5 \\
\hline $\mathrm{N} 1-\mathrm{C} 1-\mathrm{C} 2$ & $102.32(12)$ & $\mathrm{H} 7 \mathrm{~B}-\mathrm{C} 7-\mathrm{H} 7 \mathrm{C}$ & 109.5 \\
\hline $\mathrm{C} 8-\mathrm{C} 1-\mathrm{C} 2$ & $113.23(13)$ & $\mathrm{O} 3-\mathrm{C} 8-\mathrm{O} 4$ & $124.90(16)$ \\
\hline $\mathrm{N} 1-\mathrm{C} 1-\mathrm{H} 1$ & 109.9 & $\mathrm{O} 3-\mathrm{C} 8-\mathrm{C} 1$ & $125.34(15)$ \\
\hline $\mathrm{C} 8-\mathrm{C} 1-\mathrm{H} 1$ & 109.9 & $\mathrm{O} 4-\mathrm{C} 8-\mathrm{C} 1$ & $109.73(13)$ \\
\hline $\mathrm{C} 2-\mathrm{C} 1-\mathrm{H} 1$ & 109.9 & $\mathrm{O} 4-\mathrm{C} 9-\mathrm{H} 9 \mathrm{~A}$ & 109.5 \\
\hline $\mathrm{O} 6-\mathrm{C} 2-\mathrm{C} 3$ & $108.78(12)$ & $\mathrm{O} 4-\mathrm{C} 9-\mathrm{H} 9 \mathrm{~B}$ & 109.5 \\
\hline $\mathrm{O} 6-\mathrm{C} 2-\mathrm{C} 1$ & $106.68(12)$ & $\mathrm{H} 9 \mathrm{~A}-\mathrm{C} 9-\mathrm{H} 9 \mathrm{~B}$ & 109.5 \\
\hline $\mathrm{C} 3-\mathrm{C} 2-\mathrm{C} 1$ & $103.23(12)$ & $\mathrm{O} 4-\mathrm{C} 9-\mathrm{H} 9 \mathrm{C}$ & 109.5 \\
\hline $\mathrm{O} 6-\mathrm{C} 2-\mathrm{H} 2$ & 112.5 & $\mathrm{H} 9 \mathrm{~A}-\mathrm{C} 9-\mathrm{H} 9 \mathrm{C}$ & 109.5 \\
\hline $\mathrm{C} 3-\mathrm{C} 2-\mathrm{H} 2$ & 112.5 & $\mathrm{H} 9 \mathrm{~B}-\mathrm{C} 9-\mathrm{H} 9 \mathrm{C}$ & 109.5 \\
\hline $\mathrm{C} 1-\mathrm{C} 2-\mathrm{H} 2$ & 112.5 & $\mathrm{O} 5-\mathrm{C} 10-\mathrm{O} 6$ & $122.72(16)$ \\
\hline $\mathrm{O} 8-\mathrm{C} 3-\mathrm{C} 2$ & $102.26(11)$ & $\mathrm{O} 5-\mathrm{C} 10-\mathrm{C} 11$ & $125.62(16)$ \\
\hline $\mathrm{O} 8-\mathrm{C} 3-\mathrm{C} 4$ & $111.80(12)$ & $\mathrm{O} 6-\mathrm{C} 10-\mathrm{C} 11$ & $111.66(16)$ \\
\hline $\mathrm{C} 2-\mathrm{C} 3-\mathrm{C} 4$ & $103.54(13)$ & $\mathrm{C} 10-\mathrm{C} 11-\mathrm{H} 11 \mathrm{~A}$ & 109.5 \\
\hline $\mathrm{O} 8-\mathrm{C} 3-\mathrm{H} 3$ & 112.8 & $\mathrm{C} 10-\mathrm{C} 11-\mathrm{H} 11 \mathrm{~B}$ & 109.5 \\
\hline $\mathrm{C} 2-\mathrm{C} 3-\mathrm{H} 3$ & 112.8 & $\mathrm{H} 11 \mathrm{~A}-\mathrm{C} 11-\mathrm{H} 11 \mathrm{~B}$ & 109.5 \\
\hline $\mathrm{C} 4-\mathrm{C} 3-\mathrm{H} 3$ & 112.8 & $\mathrm{C} 10-\mathrm{C} 11-\mathrm{H} 11 \mathrm{C}$ & 109.5 \\
\hline $\mathrm{N} 1-\mathrm{C} 4-\mathrm{C} 3$ & $103.35(12)$ & $\mathrm{H} 11 \mathrm{~A}-\mathrm{C} 11-\mathrm{H} 11 \mathrm{C}$ & 109.5 \\
\hline $\mathrm{N} 1-\mathrm{C} 4-\mathrm{H} 4 \mathrm{~A}$ & 111.1 & $\mathrm{H} 11 \mathrm{~B}-\mathrm{C} 11-\mathrm{H} 11 \mathrm{C}$ & 109.5 \\
\hline $\mathrm{C} 3-\mathrm{C} 4-\mathrm{H} 4 \mathrm{~A}$ & 111.1 & $\mathrm{O} 7-\mathrm{C} 12-\mathrm{O} 8$ & $122.72(18)$ \\
\hline $\mathrm{N} 1-\mathrm{C} 4-\mathrm{H} 4 \mathrm{~B}$ & 111.1 & $\mathrm{O} 7-\mathrm{C} 12-\mathrm{C} 13$ & $126.78(18)$ \\
\hline $\mathrm{C} 3-\mathrm{C} 4-\mathrm{H} 4 \mathrm{~B}$ & 111.1 & $\mathrm{O} 8-\mathrm{C} 12-\mathrm{C} 13$ & $110.46(16)$ \\
\hline $\mathrm{H} 4 \mathrm{~A}-\mathrm{C} 4-\mathrm{H} 4 \mathrm{~B}$ & 109.1 & $\mathrm{C} 12-\mathrm{C} 13-\mathrm{H} 13 \mathrm{~A}$ & 109.5 \\
\hline $\mathrm{O} 1-\mathrm{C} 5-\mathrm{O} 2$ & $125.04(15)$ & $\mathrm{C} 12-\mathrm{C} 13-\mathrm{H} 13 \mathrm{~B}$ & 109.5 \\
\hline $\mathrm{O} 1-\mathrm{C} 5-\mathrm{N} 1$ & $124.93(15)$ & $\mathrm{H} 13 \mathrm{~A}-\mathrm{C} 13-\mathrm{H} 13 \mathrm{~B}$ & 109.5 \\
\hline $\mathrm{O} 2-\mathrm{C} 5-\mathrm{N} 1$ & $110.02(14)$ & $\mathrm{C} 12-\mathrm{C} 13-\mathrm{H} 13 \mathrm{C}$ & 109.5 \\
\hline $\mathrm{O} 2-\mathrm{C} 6-\mathrm{C} 7$ & $106.76(17)$ & $\mathrm{H} 13 \mathrm{~A}-\mathrm{C} 13-\mathrm{H} 13 \mathrm{C}$ & 109.5 \\
\hline $\mathrm{O} 2-\mathrm{C} 6-\mathrm{H} 6 \mathrm{~A}$ & 110.4 & $\mathrm{H} 13 \mathrm{~B}-\mathrm{C} 13-\mathrm{H} 13 \mathrm{C}$ & 109.5 \\
\hline $\mathrm{C} 7-\mathrm{C} 6-\mathrm{H} 6 \mathrm{~A}$ & 110.4 & & \\
\hline
\end{tabular}




$\begin{array}{llll}\mathrm{C} 5-\mathrm{N} 1-\mathrm{C} 1-\mathrm{C} 8 & 76.02(19) & \mathrm{C} 2-\mathrm{C} 3-\mathrm{C} 4-\mathrm{N} 1 & -27.36(15) \\ \mathrm{C} 4-\mathrm{N} 1-\mathrm{C} 1-\mathrm{C} 8 & -103.88(15) & \mathrm{C} 6-\mathrm{O} 2-\mathrm{C} 5-\mathrm{O} 1 & -0.3(3) \\ \mathrm{C} 5-\mathrm{N} 1-\mathrm{C} 1-\mathrm{C} 2 & -162.67(14) & \mathrm{C} 6-\mathrm{O} 2-\mathrm{C} 5-\mathrm{N} 1 & -179.62(15) \\ \mathrm{C} 4-\mathrm{N} 1-\mathrm{C} 1-\mathrm{C} 2 & 17.43(18) & \mathrm{C} 1-\mathrm{N} 1-\mathrm{C} 5-\mathrm{O} 1 & 2.0(3) \\ \mathrm{C} 10-\mathrm{O} 6-\mathrm{C} 2-\mathrm{C} 3 & -96.72(15) & \mathrm{C} 4-\mathrm{N} 1-\mathrm{C} 5-\mathrm{O} 1 & -178.13(17) \\ \mathrm{C} 10-\mathrm{O} 6-\mathrm{C} 2-\mathrm{C} 1 & 152.54(13) & \mathrm{C} 1-\mathrm{N} 1-\mathrm{C} 5-\mathrm{O} 2 & -178.67(14) \\ \mathrm{N} 1-\mathrm{C} 1-\mathrm{C} 2-\mathrm{O} 6 & 80.73(14) & \mathrm{C} 4-\mathrm{N} 1-\mathrm{C} 5-\mathrm{O} 2 & 1.2(2) \\ \mathrm{C} 8-\mathrm{C} 1-\mathrm{C} 2-\mathrm{O} 6 & -159.17(12) & \mathrm{C} 5-\mathrm{O} 2-\mathrm{C} 6-\mathrm{C} 7 & 178.98(17) \\ \mathrm{N} 1-\mathrm{C} 1-\mathrm{C} 2-\mathrm{C} 3 & -33.83(15) & \mathrm{C} 9-\mathrm{O} 4-\mathrm{C} 8-\mathrm{O} 3 & -6.4(3) \\ \mathrm{C} 8-\mathrm{C} 1-\mathrm{C} 2-\mathrm{C} 3 & 86.27(14) & \mathrm{C} 9-\mathrm{O} 4-\mathrm{C} 8-\mathrm{C} 1 & 171.57(15) \\ \mathrm{C} 12-\mathrm{O} 8-\mathrm{C} 3-\mathrm{C} 2 & -176.59(13) & \mathrm{N} 1-\mathrm{C} 1-\mathrm{C} 8-\mathrm{O} 3 & -8.7(2) \\ \mathrm{C} 12-\mathrm{O} 8-\mathrm{C} 3-\mathrm{C} 4 & 73.23(17) & \mathrm{C} 2-\mathrm{C} 1-\mathrm{C} 8-\mathrm{O} 3 & -123.40(18) \\ \mathrm{O} 6-\mathrm{C} 2-\mathrm{C} 3-\mathrm{O} 8 & 168.91(11) & \mathrm{N} 1-\mathrm{C} 1-\mathrm{C} 8-\mathrm{O} 4 & 173.33(13) \\ \mathrm{C} 1-\mathrm{C} 2-\mathrm{C} 3-\mathrm{O} 8 & -78.04(13) & \mathrm{C} 2-\mathrm{C} 1-\mathrm{C} 8-\mathrm{O} 4 & 58.60(17) \\ \mathrm{O} 6-\mathrm{C} 2-\mathrm{C} 3-\mathrm{C} 4 & -74.78(14) & \mathrm{C} 2-\mathrm{O} 6-\mathrm{C} 10-\mathrm{O} 5 & 3.0(2) \\ \mathrm{C} 1-\mathrm{C} 2-\mathrm{C} 3-\mathrm{C} 4 & 38.26(15) & \mathrm{C} 2-\mathrm{O} 6-\mathrm{C} 10-\mathrm{C} 11 & -176.72(15) \\ \mathrm{C} 5-\mathrm{N} 1-\mathrm{C} 4-\mathrm{C} 3 & -173.74(15) & \mathrm{C} 3-\mathrm{O} 8-\mathrm{C} 12-\mathrm{O} 7 & 0.4(2) \\ \mathrm{C} 1-\mathrm{N} 1-\mathrm{C} 4-\mathrm{C} 3 & 6.15(18) & \mathrm{C} 3-\mathrm{O} 8-\mathrm{C} 12-\mathrm{C} 13 & -177.58(14) \\ \mathrm{O} 8-\mathrm{C} 3-\mathrm{C} 4-\mathrm{N} 1 & 82.01(15) & & \end{array}$

Hydrogen-bond geometry $\left(A,{ }^{\circ}\right)$

\begin{tabular}{lllll}
\hline$D-\mathrm{H} \cdots A$ & $D-\mathrm{H}$ & $\mathrm{H} \cdots A$ & $D \cdots A$ & $D-\mathrm{H} \cdots A$ \\
\hline $\mathrm{C} 9-\mathrm{H} 9 B \cdots \mathrm{O} 5^{\mathrm{i}}$ & 0.96 & 2.53 & $3.403(3)$ & 151 \\
$\mathrm{C} 3-\mathrm{H} 3 \cdots \mathrm{O} 1^{\mathrm{ii}}$ & 0.98 & 2.62 & $3.419(2)$ & 139 \\
$\mathrm{C} 3-\mathrm{H} 3 \cdots 3^{\mathrm{ii}}$ & 0.98 & 2.61 & $3.453(2)$ & 144 \\
$\mathrm{C} 11-\mathrm{H} 11 A \cdots \mathrm{O} 7^{\mathrm{iii}}$ & 0.96 & 2.66 & $3.329(3)$ & 127
\end{tabular}

Symmetry codes: (i) $-x,-y,-z+2$; (ii) $x-1, y, z$; (iii) $x, y-1, z$. 